\title{
Identification of Potential Vertical Gas Migration Pathways above Gas Storage Reservoirs
}

\author{
Eric W. Peterson ${ }^{1, *}$, Lauren I. Martin², Dave H. Malone ${ }^{1}$ \\ ${ }^{1}$ Department of Geography-Geology, Illinois State University, Normal, IL, USA \\ ${ }^{2} \mathrm{CH} 2 \mathrm{M}$ Hill, Chicago, IL USA \\ *Corresponding author: ewpeter@ilstu.edu
}

Received April 07, 2015; Revised April 25, 2015; Accepted April 28, 2015

\begin{abstract}
Natural gas is stored underground in geologic structures throughout the United States. However, complexities associated with these geologic structures may provide vertical pathways for gas migration, and thus gas loss. Possible upward migration (loss) of natural gas in an underground gas storage field in Illinois stimulated this investigation that aims to identify potential migration pathways. Spatial analysis of volume of shale $\left(\mathrm{V}_{\mathrm{sh}}\right)$ and formation porosity $(n)$ values were conducted in conjunction with high-resolution shallow seismic surveys to identify potential vertical pathways. Surficial gas accumulations within glacial deposits were confirmed by the seismic surveys. These gas pockets accumulated by migration along steeply inclined structural discontinuities, most likely faults and fracture zones within the underlying shallow bedrock units. With the seismic technique limited to a depth of $100 \mathrm{~m}, \mathrm{~V}_{\mathrm{sh}}$ data were used to assess the reservoir's seal rocks ability to limit vertical gas migration. The $\mathrm{V}_{\mathrm{sh}}$ data indicate that the seal rocks are best classified as heterogeneous siltstones. Spatial analysis highlights an aligned pattern of low $\mathrm{V}_{\mathrm{sh}}$ values in both the reservoir rocks and the seal rocks. The low $\mathrm{V}_{\mathrm{sh}}$ values lie beneath the faults and fracture zones and the documented surficial gas deposit. Higher $n$ values for the sandstones in the reservoir area as opposed to other areas suggest porosity enhancement associated with deformation. Structural deformation, faults and fracture zones, appears to provide a pathway for vertical gas migration. However, stratigraphic (lateral) heterogeneities associated with the reservoir and seal rocks may provide additional vertical pathways.
\end{abstract}

Keywords: volume of shale calculations, seismic survey, structural deformation, illinois basin, porosity

Cite This Article: Eric W. Peterson, Lauren I. Martin, and Dave H. Malone, "Identification of Potential Vertical Gas Migration Pathways above Gas Storage Reservoirs." World Journal of Environmental Engineering, vol. 3, no. 2 (2015): 23-31. doi: 10.12691/wjee-3-2-1.

\section{Introduction}

Natural gas is used for many purposes in residential, commercial, and industrial settings, as well as for vehicle fuel and electric power. Although natural gas is consumed year around, the majority of consumption in the upper Midwest occurs during the winter for domestic heating purposes. To meet the demand during the winter months, gas suppliers must increase available supply through storage. Since 1915, natural gas has been stored underground in order to meet the winter demand. Three types of underground gas storage facilities exist: salt caverns; aquifers; and depleted oil and gas reservoirs [1]. From 1973 to 2004, the total capacity of gas storage fields within the United States rose from 13,900 million cubic meters $\left(\mathrm{Mm}^{3}\right)$ to $23,000 \mathrm{Mm}^{3}$ [2]. Underground gas storage in geologic structures is common throughout the United States, but is most popular in the Midwest and the Northeast [1].

The process of storing natural gas in natural geological structures is complex. Gas is initially delivered by pipeline and injected into structural reservoirs through injection/withdrawal wells. The gas injection cycle at
Midwest gas storage fields runs from May to late October. Withdrawal begins when the demand of gas for fuel during the winter months exceeds pipeline capacity. To reach maximum capacity by the winter, a reservoir needs to be at a certain pressure and capacity each week and month during injection. The reservoir and flow pressure are monitored on a daily basis to ensure proper flow rates and pressures within the reservoir.

While storage reservoir locations are determined based upon the presence of structural traps and/or confining layers, natural gas is a low-density fluid capable of migrating outside reservoir boundaries along any available flow path. The mobility of the natural gas coupled with lithological and structural heterogeneities within the formations provide potential pathways for vertical (upward) gas migration. For example, at the Yaggy Gas Storage Field in Hutchinson, Kansas, gas migrated out of the reservoir into the overlying formations and to the surface [3]. The escape of the gas resulted in two explosions at the surface, destroying several buildings and killing two people. At the Gaz de France underground gas storage field northeast of Paris, France, gas preferentially migrated to the limb of an anticline [4].

In Illinois, gas supply companies operate large underground gas storage reservoirs in deep saline 
reservoirs, which are mainly in Cambrian (Eau Claire and Mt. Simon Formations) and Ordovician (St. Peter Sandstone) units. One of these storage reservoirs was studied in detail during this investigation. Unfortunately the exact location and name of this particular reservoir cannot be discussed by mandate from the Department of Homeland Security. A general geologic description of the area is provided below to ensure needed scientific background.

Recently, retardation of crop growth was attributed to gas that migrated to the surface from the deep storage reservoir. Preliminary work suggests that the crop damage is closely related to gas inventory within the reservoir. At low inventory, crop damage is minimal. However, at higher inventories, gas is documented in the shallow subsurface, leading to the extermination of plant life in the area. The presence of the gas in the shallow subsurface suggests that gas may migrate vertically out of the reservoir. This work details an investigation addressing two questions: 1) Are there potential vertical pathways within the seal rocks that allow gas to escape from the reservoir? and 2) Are there locations above the reservoir where escaped gas can accumulate? The questions were addressed using a two-pronged approach incorporating volume of shale $\left(\mathrm{V}_{\mathrm{sh}}\right)$ and formation porosity (n) calculations coupled with high-resolution shallow seismic surveys reported by [5]. These data provide a means to assess possible vertical pathways associated with lithological and structural variability within the reservoir and to identify the presence of gas within the surficial deposits and shallow bedrock.

If the gas is migrating vertically and is accumulating in the overlying formations, then this gas could be recovered and either reinjected or used. For the reservoir in question, the principal reservoir units include the Mount Simon Sandstone and sandstones within the Eau Claire Formation. Siltstones and shales of the Eau Claire Formation function as seal rocks. Although some shale exists nearly everywhere within these units, gas migration through fractures or complexly connected sand bodies within the Eau Claire is possible. Thus, documenting potential fluid conduits is essential for properly managing this gas storage field.

\section{Geologic Setting}

\subsection{Stratigraphy and Sedimentology}

Ordovician and Cambrian rocks that have undergone episodes of folding and faulting dominate the geology of the gas-storage reservoir area (Figure 1). The main storage unit of the reservoir is the Cambrian Mt. Simon Sandstone. The Mt. Simon is a very fine to very coarse grained, moderately to poorly sorted sandstone with discontinuous shale intervals present throughout the unit. With rounded to sub-angular sand grains, the porosity ranges between 10 and 15\%, and the permeability varies between 15 and 185 millidarcies [6].

Overlying the Mt. Simon Sandstone is the Cambrian Eau Claire Formation, which is envisioned as the seal rock. The Eau Claire contact with the Mount Simon is intercalated, repeatedly grading (three times) from a siltstone to a sandstone. The four siltstone intervals, Mt.
Simon Cap Rock, C Cap Rock, B Cap Rock, and A Cap Rock for oldest to youngest, serve as seal rocks to the reservoir intervals. However, the siltstones are heterogeneous, with some sandstone, dolomite, and discontinuous shale beds. The upper most unit, A Cap Rock, serves as the seal rock for the entire reservoir. Sand units consist of sandstone with dolomite and shale interbeds and are used for gas storage. The sands are designated as the A sand (youngest), B sand, and the C sand (oldest). Within the Eau Claire Formation sand units, $n$ values range between 17 and 19\%, and permeabilities range between 150 and 556 millidarcies [6]. Porosity and permeability values for the siltstone and shale layers have not been reported.

Overlying the Eau Claire is the Galesville Sandstone, followed by the Ironton Sandstone and then the Franconia Sandstone (Figure 1). These three Cambrian aged sandstones are described as very fine- to coarse-grained sandstones with shaly-dolomitic beds. The Trempealeau Group, a micro- to very fine-crystalline dolomite, is the uppermost Cambrian unit.

The Ordovician stratigraphy consist of the Prairie du Chien Group, the Ancell Group, the Platteville Group, and the Galena Group (Figure 1). The Prairie du Chien Group is comprised of the Gunter Sandstone, Oneota Dolomite, New Richmond Sandstone, and the Shakopee Dolomite. As the name implies, the Gunter Sandstone is typically a sandstone; however, in the reservoir area the formation is a micro- to medium-crystalline dolomite with intermittent sandstone beds. Overlying the Gunter is the Oneota Dolomite, a micro- to medium-crystalline dolomite with a vuggy inter-crystalline porosity. The New Richmond Sandstone is fine- to coarse-grained sandstone that is unconsolidated in areas. The Shakopee Dolomite is a micro- to fine-crystalline dolomite that has intermittent sandstone beds.

In the area, the Ancell Group is represented by the St. Peter Sandstone. The St. Peter Sandstone unconformably overlies the Shakopee Formation. There is more than $30 \mathrm{~m}$ of paleotopographic relief along this unconformity, part of which is a poorly developed karst topography developed on the top of the Shakopee. The St. Peter Sandstone consists of white and light gray, fine to medium, wellrounded grains of quartz sand that are cemented with calcite, iron oxide, or silica. The sand grains are typically frosted and cross-bedding is common. While not incorporated as a reservoir unit in this area, the St. Peter Sandstone has been used as a reservoir unit in other Midwest storage fields.

The St. Peter Sandstone is conformably overlain by the Platteville and Galena Groups. These units are dominantly carbonates with minor amounts of calcareous shale and bentonite [7]. Both of these units are coarsely fossiliferous and were probably deposited in a stable, low energy environment. In most of northern Illinois, Galena and Platteville strata have been dolomitized.

The Paleozoic units are overlain by the late Wisconsinan (Woodfordian) tills and related materials of the Wedron and Mason groups [8].

Your paper must use a page size corresponding to A4 which is $210 \mathrm{~mm}$ wide and $297 \mathrm{~mm}$ long. The margins are set as follows: top $=15 \mathrm{~mm}$, bottom $=15 \mathrm{~mm}$, right $=17.5$ $\mathrm{mm}$, left $=20 \mathrm{~mm}$. Your paper must be in two column format with a space of 1.93 characters between columns. 


\begin{tabular}{|c|c|c|c|c|c|c|}
\hline Period & Group & Formation & $\begin{array}{c}\text { Reservoir } \\
\text { Unit }\end{array}$ & $\begin{array}{c}\text { Thickness } \\
(\mathrm{m})\end{array}$ & $\begin{array}{l}\text { Graphic } \\
\text { Column } \\
\end{array}$ & Lithology \\
\hline Quaternary & Wedron & & & $9-24$ & & Till \\
\hline \multirow{6}{*}{ 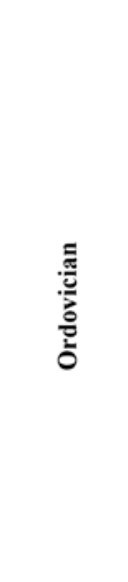 } & Platteville & & & $0-36$ & & Dolomite \\
\hline & Ancell & St. Peter & & $0-54$ & & Sandstone \\
\hline & \multirow{4}{*}{$\begin{array}{l}\text { Prairie du } \\
\text { Chien }\end{array}$} & Shakopee & & $30-60$ & & Dolomite \\
\hline & & $\begin{array}{c}\text { New } \\
\text { Richmond }\end{array}$ & & $24-30$ & & Sandstone \\
\hline & & Oneota & & $36-49$ & 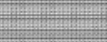 & Dolomite \\
\hline & & Gunter & & $30-39$ & & Dolomite with Sandstone \\
\hline \multirow{12}{*}{ 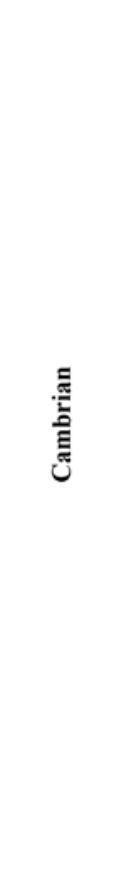 } & Trempealeau & & & $29-42$ & & Dolomite \\
\hline & & Franconia & & $36-42$ & & Sandstone \\
\hline & & Ironton & & $23-33$ & & Sandstone \\
\hline & & Galesville & & $24-29$ & & Sandstone \\
\hline & & \multirow{7}{*}{ Eau Claire } & $\begin{array}{l}\text { A Cap } \\
\text { Rock }\end{array}$ & $45-60$ & & Siltstone to Sandstone \\
\hline & & & A Sand & $18-21$ & & Sandstone \\
\hline & & & $\begin{array}{l}\text { B Cap } \\
\text { Rock }\end{array}$ & $15-21$ & & Siltstone and Dolomite \\
\hline & & & B Sand & $15-18$ & & Sandstone \\
\hline & & & C Cap Rock & $9-12$ & & Dolomite \\
\hline & & & C Sand & $9-12$ & & Sandstone \\
\hline & & & Mt. Simon & $6-9$ & & Siltstone \\
\hline & & Mt. Simon & & $\sim 600$ & & Sandstone \\
\hline
\end{tabular}

Figure 1. Stratigraphic column for the area

\subsection{Structural Geology}

The gas storage reservoir occupies a small domal structure within the northern segment of the LaSalle Anticlinorium [9]. A strongly asymmetric fold, the LaSalle Anticlinorium is well-exposed in the western part of LaSalle County, IL, but elsewhere occurs only in the subsurface. The structure extends along a trend of about $\mathrm{N} 20^{\circ} \mathrm{W}$ from southwestern Indiana to north-central Illinois. In north-central Illinois, the anticlinorium is a narrow fold with a steeply dipping (as much as $35^{\circ}$ ) western limb and a gently dipping eastern limb (generally $<^{\circ}$ ). In southern Illinois, it is a broad belt composed of several folds of about equal size. The deformation history of the structure was long and episodic. During the late Ordovician, the anticline began to form, but most of the uplift occurred immediately before, during, and after deposition of Pennsylvanian strata. The structural form, distribution and orientation of folds, thicknesses of stratigraphic units, and episodic fold development suggest that the entire anticlinorium is a bend produced by differential uplift and tilting of basement crustal blocks rather than a buckle produced by horizontal compression [10].

Within the study area, faults and folds that define the structure of the gas storage area, as well as the extent of the field, are not completely known. Most of the structural data in this area were obtained from well logs and gravity surveys. At the study site, four or more faults partition the reservoir with structural closure used for gas storage. The total closure of the structure is designed to hold at least 1 billion cubic meters $\left(\mathrm{bm}^{3}\right)$ of natural gas and as much as 2 $\mathrm{bm}^{3}$.

Within the field, there is one major fault that constitutes the frontal reverse fault that facilitated folding of Paleozoic strata. The displacement is such that on the north side, a company is quarrying the Platteville Formation for aggregate, while on the south side another company is mining the St. Peter Sandstone for silica. The 
estimated vertical displacement along the main fault is 20$50 \mathrm{~m}$. Within the northern portion of the field, the Platteville Formation is the surficial bedrock unit, but the unit has been eroded over most of the southern portion. With the Platteville Formation eroded, the St. Peter Sandstone is the major surficial bedrock unit in the southern section. One exception is at the top of an elongated oval dome where the St. Peter Sandstone has been removed to reveal the Shakopee Dolomite (see [5] Figure 10).

As a result of the main faults, the reservoir has been divided into zones. They are the A Sand North, the A Sand South, the B Sand North, the B Sand South, the C Sand North, the C Sand South, the Mt. Simon Sandstone North, and the Mt. Simon Sandstone South. Each is used for gas storage and has a corresponding seal rock. Surficial gas shows within the southern section of the field indicate that there may be undocumented faults, fractures, and joints, which may serve as potential vertical pathways (see [5], Figure 10).

\section{Methods/Materials}

\subsection{Volume of Shale $\left(\mathbf{V}_{\mathrm{sh}}\right)$}

Textural heterogeneity within each unit was assessed through $\mathrm{V}_{\mathrm{sh}}$ calculations. The $\mathrm{V}_{\mathrm{sh}}$ measurement is a proxy for grain size. Following the method of [11], $V_{s h}$ values for all units in the reservoir were calculated using gamma ray counts obtained from gamma ray logs calibrated to well-stratigraphic logs. A gamma ray log records the natural gamma ray radiation emitted from uranium, thorium, and potassium found within in shale or clays but found in limited quantities within sandstone. After calibration to a stratigraphic-log, the differing counts indicate the amount of shale that is present. The maximum gamma ray value $\left(\gamma_{\max }\right)$ represents a shale value of 1.00 or 100 percent, while the minimum value $\left(\gamma_{\min }\right)$ corresponds to a no shale present, e.g. sand or larger grained material [12]. For each well, $\gamma_{\min }$ and $\gamma_{\max }$ are determined independently [12]. The gamma ray curve is quantified into a percentage, which represents the $\mathrm{V}_{\mathrm{sh}}$ using equation (1):

$$
\mathrm{V}_{\mathrm{sh}}=\left(\gamma_{\log }-\gamma_{\min }\right) /\left(\gamma_{\max }-\gamma_{\min }\right)
$$

where $\gamma_{\log }$ is the gamma ray value at a specified depth [12].

The uncalibrated gamma ray logs cannot be directly compared among holes. However, comparisons among holes can be made after each well log is standardized to a specific test pit [12]. The equipment used for gamma ray logging is calibrated to an international standard, and as a result, readings vary on a daily basis, which causes a certain amount of error. The amount of error is kept to a minimum with daily checks of the instrument calibration and regular calibration to the international standard.

Twenty-nine (29) wells within the reservoir have both gamma ray logs and detailed stratigraphic logs (Figure 2). Deviations in the gamma ray readings and material descriptions from the well logs were used to delineate the different units within the reservoir. For each well, $\mathrm{V}_{\mathrm{sh}}$ values were calculated for the seven units within the Eau Claire Formation; the A cap rock, A sand, B cap rock, B sand, C cap rock, C sand, and Mt. Simon cap rock, and for the Mt Simon Sandstone. For each unit, a mean $\mathrm{V}_{\mathrm{sh}}$ value, a standard deviation $(\sigma)$, and a coefficient of variation (C.V.) were calculated. Spatial distributions of the $V_{\text {sh }}$ values for each unit were generated using krigging analysis.

\subsection{Porosity (n)}

Three boreholes were drilled along the edges of the storage field where observation wells were later installed (Figure 2). The wells extend into the Mt. Simon Sandstone, and the well logs indicate that the formations exhibit the same structural and hydrologic properties identified in the formations during past drilling (unpublished data - bore logs). A bulk-density logger recorded the rock and the total formation density every 0.15 meters as the logging apparatus advanced from the bottom of the hole up to the surface. The difference between the two densities provides the calculated formation $n$. As with the $\mathrm{V}_{\text {sh }}$ values, a mean $n$ value, a standard deviation $(\sigma)$, and a C.V. were calculated for each unit.

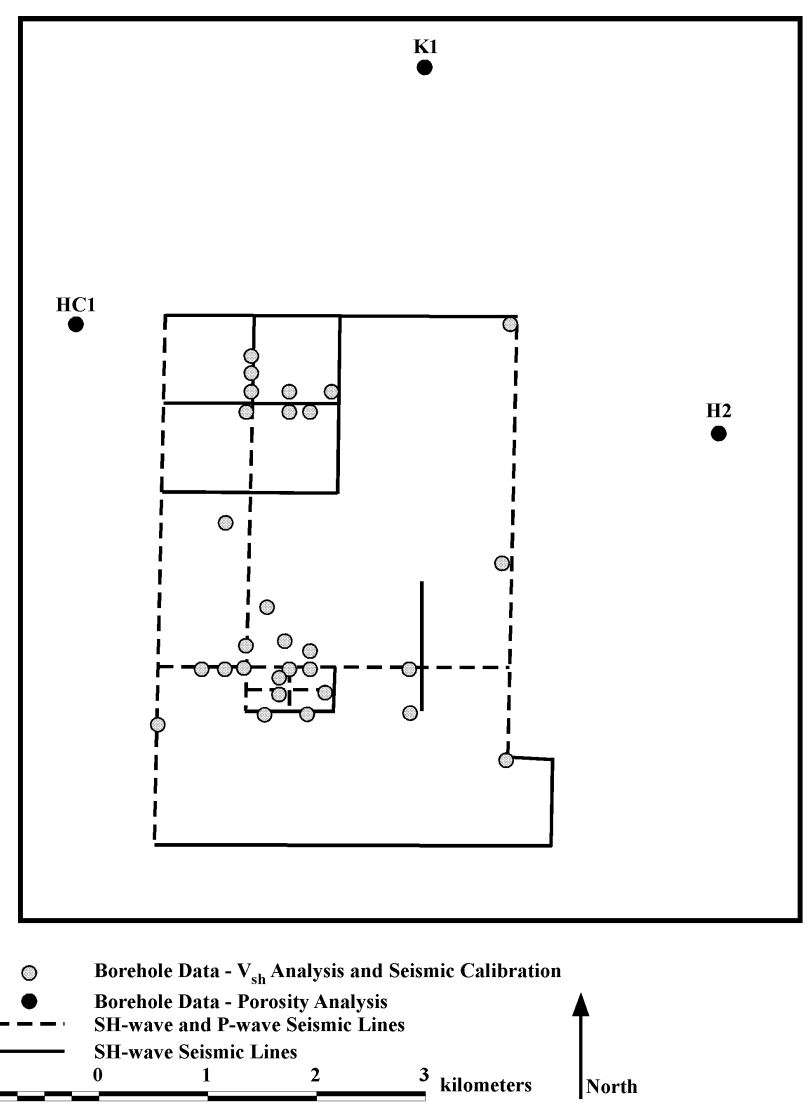

Figure 2. Spatial relationship among the wells providing borehole data and the seismic lines. As mentioned within the text, true coordinates are not provided to ensure confidentiality

\subsection{Shallow Seismic Reflection}

A detailed description of the seismic methods is provided in [13], and complete details concerning the acquisition, processing, and interpretation of the seismic data are presented in [5]. A brief description is included here for background. Horizontal shear wave (SH-wave) seismic reflection was used to determine soil and rock geometry inferred by physical property changes allowing observation of structural deformations, and lithological changes. SH-waves are unaffected by changes in pore 
fluid and cannot provide any information about the presence of gas. Compressive (P-wave) seismic reflection surveys have been used to delineate changes in shallow subsurface density conditions created by changes in the pore fluid content [13]. Small quantities of gas within pore fluid produces a very strong impedance contrast with surrounding rock. The strong impedance coupled with the energy absorption by the gas generate a signal that can be observed in the P-wave reflection surveys [13].

Within the boundary of the reservoir, $24 \mathrm{~km}$ of highresolution shear-wave ( $\mathrm{SH}$-wave) seismic reflection profiles and $15 \mathrm{~km}$ of high-resolution P-wave seismic reflection profiles were acquired during the summer of 2004 (Figure 2). The profile lines were chosen to intersect all of the known faults and to reveal the dip component at the surface of the bedrock.

\section{Results}

\subsection{Volume of Shale}

Volume-of-shale values for the reservoir were calculated from gamma ray logs for 29 wells throughout the field. As expected, the average $V_{\text {sh }}$ values indicate a lithological difference between the reservoir units $(<30 \%$ shale) and the seal rocks ( $>61 \%$ shale) (Table 1$)$. Within the individual wells, the sandstones exhibited $\mathrm{V}_{\text {sh }}$ values from $41 \%$ to $9 \%$, but the standard deviation (5\% to $7 \%$ ) and the C.V. (0.19 to 0.43) for each unit indicates that the sandstones are more heterogeneous than the seal rocks (Table 1). While the seal rocks' $\mathrm{V}_{\mathrm{sh}}$ values varied from the $86 \%$ to $48 \%$, the C.V. values were below 0.12 , suggesting more homogeneity within each unit.

Table 1. Calculated $V_{\text {sh }}$ values for each reservoir unit and seal rock unit. Values represent the percentage of the formation that is shale.

\begin{tabular}{|c|c|c|c|c|c|c|c|c|}
\hline Well & A Cap & A Sand & B Cap & B Sand & C Cap & C Sand & Mt. Simon Cap & Mt. Simon \\
\hline A & 67 & 26 & 69 & 22 & 65 & 38 & 67 & 24 \\
\hline $\mathrm{B}$ & 58 & 24 & 70 & 12 & 66 & 33 & 82 & 15 \\
\hline $\mathrm{C}$ & 42 & 13 & 55 & 9 & 48 & 31 & 60 & 17 \\
\hline $\mathrm{D}$ & 58 & 19 & 73 & 14 & 63 & 32 & 81 & 20 \\
\hline $\mathrm{E}$ & 64 & 22 & 77 & 21 & 58 & 40 & 73 & 35 \\
\hline $\mathrm{F}$ & 57 & 17 & 71 & 13 & 58 & 24 & 69 & 19 \\
\hline G & 59 & 19 & 73 & 16 & 60 & 31 & 70 & 23 \\
\hline $\mathrm{H}$ & 57 & 19 & 71 & 34 & 67 & 36 & 78 & 15 \\
\hline I & 60 & 12 & 70 & 9 & 86 & 20 & 62 & 18 \\
\hline $\mathrm{J}$ & 68 & 20 & 71 & 39 & 64 & 32 & 80 & 24 \\
\hline $\mathrm{K}$ & 70 & 15 & 74 & 8 & 67 & 28 & 77 & 19 \\
\hline $\mathrm{L}$ & 61 & 28 & 73 & 20 & 72 & 41 & 81 & 27 \\
\hline M & 71 & 11 & 70 & 26 & 53 & 25 & 62 & 17 \\
\hline $\mathrm{N}$ & 67 & 15 & 71 & 16 & 70 & 33 & 76 & 27 \\
\hline $\mathrm{O}$ & 59 & 15 & 72 & 13 & 67 & 24 & 82 & 17 \\
\hline $\mathrm{P}$ & 67 & 13 & 66 & 26 & 66 & 31 & - & - \\
\hline $\mathrm{Q}$ & 65 & 23 & 72 & 11 & 65 & 35 & 75 & 24 \\
\hline $\mathrm{R}$ & 64 & 21 & 70 & 16 & 65 & 25 & 65 & 11 \\
\hline $\mathrm{S}$ & 60 & 14 & 71 & 11 & 64 & 28 & 74 & 20 \\
\hline $\mathrm{T}$ & 64 & 20 & 78 & 15 & 66 & 29 & 76 & 22 \\
\hline $\mathrm{U}$ & 55 & 18 & 70 & 20 & 66 & 37 & 78 & 33 \\
\hline $\mathrm{V}$ & 58 & 15 & 74 & 15 & 52 & 25 & 63 & 13 \\
\hline W & 64 & 20 & 66 & 9 & 64 & 35 & 80 & 16 \\
\hline$X$ & 53 & 16 & 56 & 8 & 65 & 26 & 65 & 25 \\
\hline $\mathrm{Y}$ & 71 & 24 & 72 & 22 & 70 & 35 & 69 & 24 \\
\hline $\mathrm{Z}$ & 57 & 22 & 56 & 13 & 60 & 33 & 76 & 28 \\
\hline AA & 62 & 31 & 74 & 26 & 66 & 31 & 74 & 27 \\
\hline $\mathrm{AB}$ & 40 & 18 & 65 & 21 & 61 & 33 & 71 & 35 \\
\hline $\mathrm{AC}$ & 66 & 14 & 69 & 16 & 50 & 26 & 73 & 21 \\
\hline $\mathrm{AD}$ & 65 & 14 & 70 & 18 & 69 & 16 & 69 & 29 \\
\hline Mean & 61 & 19 & 70 & 17 & 64 & 30 & 73 & 22 \\
\hline$\sigma$ & 7 & 5 & 5 & 7 & 7 & 6 & 7 & 6 \\
\hline C.V. & 0.12 & 0.27 & 0.08 & 0.43 & 0.11 & 0.19 & 0.09 & 0.28 \\
\hline
\end{tabular}

Both the B cap rock and the Mt. Simon cap rock appear to be adequate seal rocks with average $\mathrm{V}_{\mathrm{sh}}$ values of $70 \%$ and $73 \%$ respectively. The two units are also the most homogeneous units as indicated by the C.V. values below 0.10 . The Eau Claire Formation seal rock of the reservoir (A cap rock) is heterogeneous and may be less of a seal than previously thought. The data imply that the A cap rock is a siltstone $\left(\mathrm{V}_{\mathrm{sh}}\right.$ value $\left.=40-71 \%\right)$ and that nowhere within the reservoir does the formation grade to shale in a large enough quantity to be classified as a shale.

The distributions of $\mathrm{V}_{\mathrm{sh}}$ values (Figure 3) reveal spatial heterogeneity within the individual units and among the units, especially in the north and south reservoir systems. Spatially there is a trend among the layers where anomalously low $\mathrm{V}_{\mathrm{sh}}$ values are vertically aligned (Figure 3). Within the anomalous areas, the $\mathrm{V}_{\text {sh }}$ values are below $48 \%$ and $8 \%$ for the seal rocks and reservoir units, respectively. A sampling bias is present within the data that may skew the distributions. The areas with a high distribution of wells show the widest range of $\mathrm{V}_{\text {sh }}$ values.

The C sand of the Eau Claire Formation is the most homogeneous sandstone (C.V. value of 0.19 ) of the four units used for gas storage. However, the $\mathrm{V}_{\mathrm{sh}}$ data indicate that there are areas within the $C$ sand that are very shale 
rich. The B sand of the Eau Claire Formation has the least amount of shale and is the most heterogeneous (C.V. value of 0.43). Discontinuous shale beds exist throughout each unit, but because the beds are discontinuous, they do not serve as a seal, just a minor divider between layers within the same unit in a specific column. All of the other units have high variability in the location of the discontinuous shale beds and the quantity of discontinuous shale beds. While the variability could be associated with the discontinuous shale beds irregularly spaced within the sandstone and siltstone beds, the spatial patterns support a hypothesis that the heterogeneity is a result of the structural deformation associated with the formation of the anticlinorium.

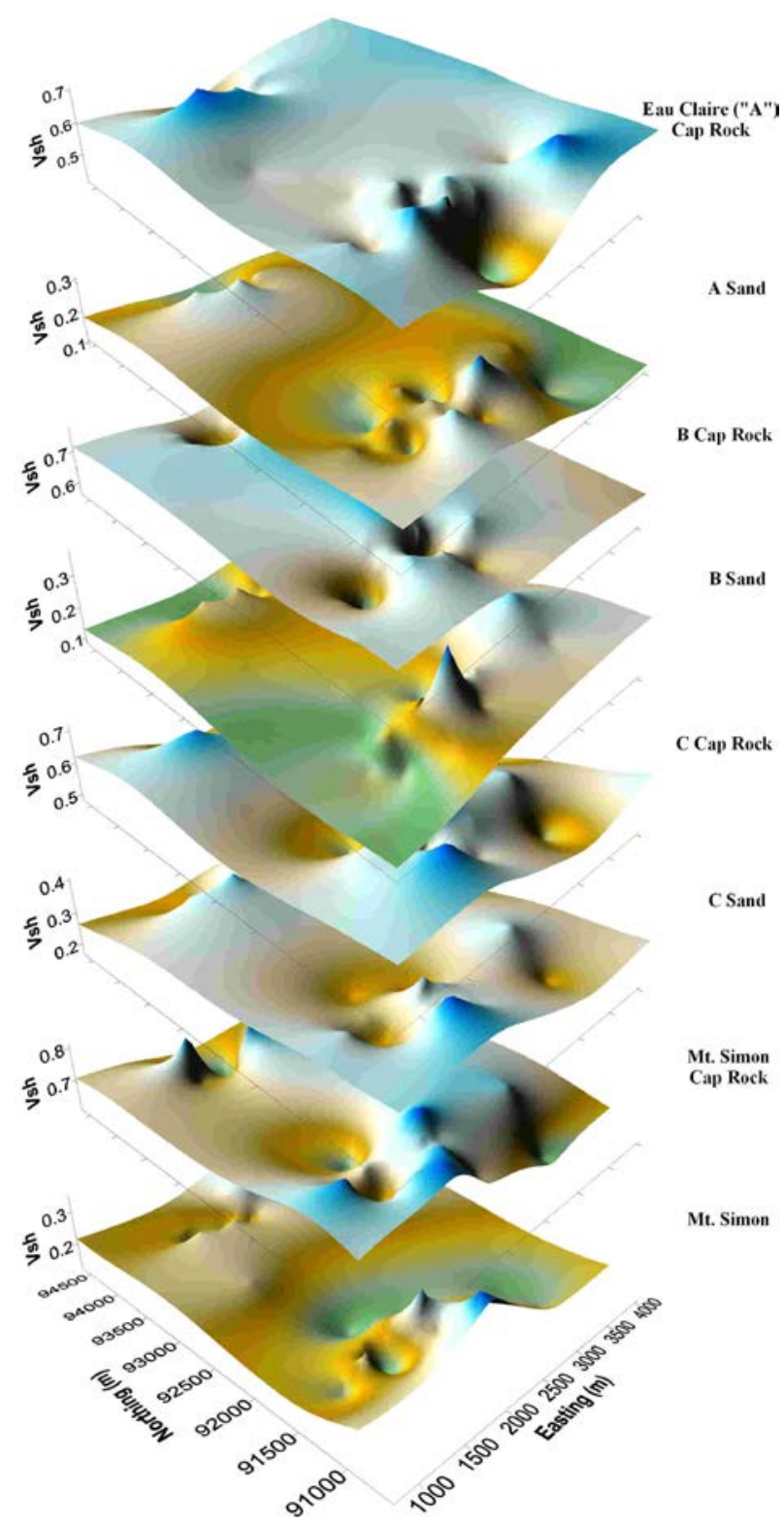

Figure 3. Spatial distribution of $\mathrm{V}_{\mathrm{sh}}$ values for each unit within the reservoir. Within in the southwestern section of the study area, there is a vertical plane of low $V_{\text {sh }}$ values through all of the units. Please note that the $\mathrm{V}_{\mathrm{sh}}$ scale (z-axis) varies with each unit, and that the reservoir unit values range between 0.1 to 0.4 , while the seal rocks values range from 0.5 to 0.8

\subsection{Porosity (n)}

Formation porosity values were calculated for the three wells installed for the project, which will be referred to as
K1, H2, and HC1 (Table 2 and Figure 4). Observations and descriptions accompanying the stratigraphic logs for the three wells corroborate the density derived $n$ values. The Platteville Formation, Shakopee Formation, Oneota Formation, Gunter Sandstone, and the Trempealeau Formation all have $n$ values less than $10 \%$. The St. Peter Sandstone, New Richmond Sandstone, Franconia Formation, Ironton Formation, and Galesville Formation have $n$ values exceeding 20\% (Figure 4). The St. Peter Sandstone and the Shakopee Formation have the most uniform $n$ values as indicated by the C.V. values of 0.06 (Table 2).

Table 2. Formation porosity values (as \%).

\begin{tabular}{ccccccc}
\hline Formation & K1 & H2 & HC1 & Mean & $\sigma$ & C.V. \\
\hline Platteville & 7 & 13 & 6 & 9 & 4 & 0.40 \\
St. Peter & 26 & 28 & 25 & 26 & 1 & 0.06 \\
Shakopee & 8 & 9 & 8 & 8 & 1 & 0.06 \\
New Richmond & 20 & 23 & 19 & 21 & 2 & 0.10 \\
Oneota & 8 & 11 & 9 & 9 & 1 & 0.12 \\
Gunter & 6 & 8 & 8 & 7 & 1 & 0.19 \\
Trempealeau & 6 & 8 & 6 & 7 & 1 & 0.15 \\
Franconia & 43 & 18 & 17 & 26 & 15 & 0.58 \\
Ironton & 46 & 20 & 14 & 27 & 17 & 0.64 \\
Galesville & 56 & 25 & 24 & 35 & 18 & 0.52 \\
Eau Claire A Cap & 26 & 21 & 20 & 22 & 3 & 0.12 \\
A Sand & 20 & 23 & 20 & 21 & 2 & 0.08 \\
B Cap & 6 & 11 & 9 & 8 & 2 & 0.30 \\
B Sand & 20 & 20 & 19 & 20 & 1 & 0.05 \\
C Cap & 6 & 12 & 12 & 10 & 3 & 0.34 \\
C Sand & 15 & 19 & 17 & 17 & 2 & 0.11 \\
Mt. Simon Cap & 11 & 14 & 13 & 13 & 2 & 0.15 \\
Mt. Simon Sand & 19 & 22 & 20 & 21 & 2 & 0.08 \\
\hline Within the & $56 r a g e$ & 13 & 25 & \\
\hline
\end{tabular}

Within the storage reservoir, average formation $n$ values ranged from 8 to 21\% (Figure 4) Porosity values for the seal rocks were below $13 \%$ with the exception of the A cap rock, which had the highest average porosity, $22 \%$, and highest single-well porosity (26\%) among all reservoir units within the field.

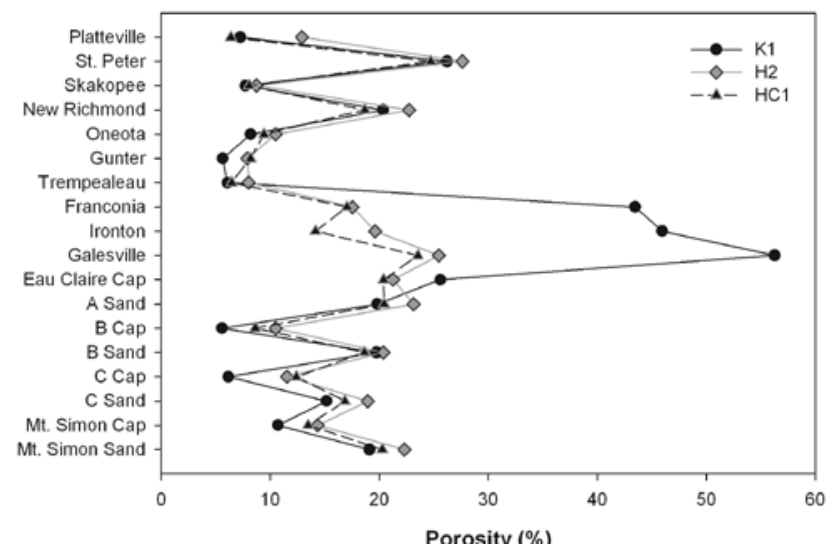

Figure 4. Average porosity values per formation from the three observation boreholes.

\subsection{Seismic}

The SH-wave survey reached a depth of approximately a hundred meters, intersecting the surficial bedrock. The analysis of the $\mathrm{SH}$-wave seismic reflection profiles in 
combination with the borehole information allowed a detailed examination of the top of four lithologic units: New Richmond, Shakopee, St Peter Sandstone, and Platteville as well as of the overlying Wisconsin glacial sediments of the Wedron Group. The seismic profiles confirm the presence of the main vertical fault with $45 \mathrm{~m}$ displacement, and identified a secondary fault in the southwestern section of the reservoir (Figure 5). From the data, [5] created surface maps for the individual layers and concluded that the units are affected by four or more additional faults that partition the reservoir and by numerous small fractures.

The P-wave surveys show high amplitude P-wave reflections are only present south of the major fault. The high amplitude reflections outline an elongate dome with a SW-NE trend. The surveys indicate that the dome is a pocket of gas that has migrated from the reservoir below. Most of the gas is located within the Shakopee Dolomite, where it is stored within fractures as indicated by the presence of high-amplitude reflections observed along fractures where the St Peter Sandstone is missing. The gas is not solely confined in the Shakopee Dolomite; highamplitude reflections illustrate that gas crosses through the St Peter Sandstone, reaching the Wedron till. The locations of the high-amplitude reflections within the Wedron till coincide with crop damage attributed to the presence of gas at the ground surface.
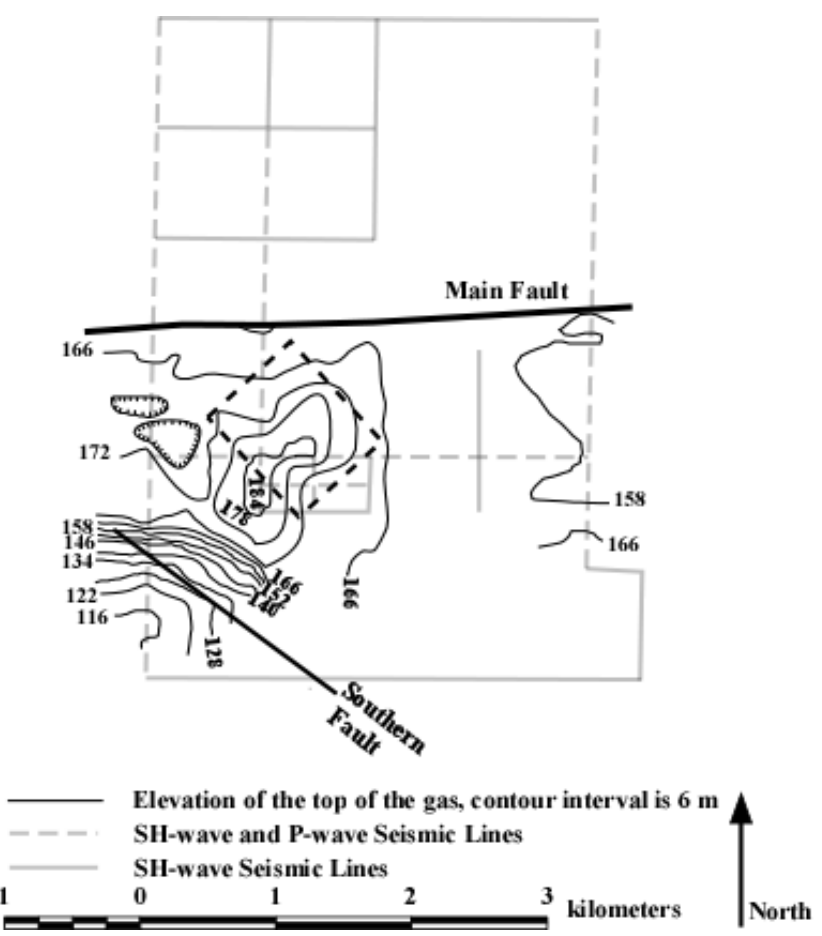

Figure 5. Location of surficial gas and the two dominant faults. The surface topography is relatively flat in the area with an elevation of roughly 200 to $208 \mathrm{~m}$. The contour lines represent the elevation of the top of the surficial gas. The seismic lines provide spatial relation to Figure 2. The dashed black box highlights the area where low $\mathrm{V}_{\mathrm{sh}}$ values are vertically aligned (See Figure 3)

\section{Discussion}

Natural gas storage began approximately 45 years ago within the reservoir. Since that time, most of the gas has been injected into the Mt. Simon Sandstone. Yet only about five percent of the total amount of natural gas within the reservoir is stored in the Mt. Simon Sandstone. Initially, the Mt. Simon Sandstone was intended to be the only formation used for gas storage. However, as a result of the 45 meters of displacement along the main fault, the Mt. Simon Sandstone is in direct communication with the $\mathrm{B}$ sand and $\mathrm{C}$ sand. Similarly, direct communication between the A sand, B sand, and C sand is accommodated by the main fault and the additional fault zones. The presence of the main fault also provides contact between the A sand and the Eau Claire Formation A cap rock and possibly the Galesville Sandstone. This connection has allowed the Eau Claire A, B, and C sands to be used for storage with the siltstone seal rocks dividing each unit. The main fault is not the only potential pathway for gas ascension. The heterogeneity associated with the $V_{\text {sh }}$ values within and among the units coupled with the presence of other faults provides alternative migration routes (Figure 5).

To function as trapping mechanisms, the seal rocks require homogeneity and a sufficient volume of shale. The $\mathrm{V}_{\mathrm{sh}}$ data indicate that the seal rocks are a siltstone with varying amounts of clay. Mud logs from the three installed wells corroborate the $\mathrm{V}_{\text {sh }}$ calculations. An examination of the $V_{\text {sh }}$ data for the Eau Claire Formation A cap rock reveals that the uppermost 15 to $30 \mathrm{~m}$ contain less clay material than the underlying portion of the A cap rock. Throughout the field, the $\mathrm{V}_{\text {sh }}$ values for the Eau Claire Formation A cap rock vary from $40 \%$ to $71 \%$. With gas already migrating to the upper units of the reservoir via the faults, the $V_{\text {sh }}$ values indicate that the $A$ cap rock may not be sufficient to prevent upward migration of gas into the units above the reservoir.

Although the Mt. Simon Sandstone has less shale than the Eau Claire Formation, the $\mathrm{V}_{\mathrm{sh}}$ data confirm the presence of discontinuous shale beds within the Mt. Simon Sandstone. These beds could create heterogeneity within the unit and influence the vertical migration of the natural gas. When present, the beds should restrict the vertical migration and when absent, allow for the vertical migration. The evidence of vertical migration indicates that the shale beds do not limit vertical migration.

The spatial distribution of the $\mathrm{V}_{\mathrm{sh}}$ values reveals a heterogeneity more complex than originally believed. This complex geology suggests that gas may migrate vertically towards the surface along areas with low $\mathrm{V}_{\mathrm{sh}}$. Within both the reservoir units and the seal rocks, areas of low shale content are vertically aligned (Figure 3 and Figure 5). The spatial pattern suggests that the heterogeneity in $V_{\text {sh }}$ values may be a result of structural deformation associated with the formation of the LaSalle Anticlinorium. Logs taken during the placement of the wells show evidence of unconsolidated materials within the reservoir sands and unusually high porosities within the reservoir seal rocks. Regardless of whether the low $\mathrm{V}_{\text {sh }}$ values indicate structural deformation orf lithological differences within units, the alignment of the low $\mathrm{V}_{\mathrm{sh}}$ areas highlight possible vertical connections among the units and correspond to the location where gas is located nearest the surface. While no information about the potential for migration is known for the units overlying the reservoir, if the spatial pattern of the $\mathrm{V}_{\mathrm{sh}}$ values is associated with structural deformation then logically, the units above the reservoir would also be impacted by the structural deformation. 
In Illinois, $n$ values for the St. Peter Sandstone, Galesville Sandstone, Eau Claire Formation, and the Mt. Simon Sandstone have been reported from areas that have undergone structural deformation at some point, dome structures and anticlines [6]. Reported $n$ values vary for the St. Peter Sandstone (14 to 18\%), the Galesville Sandstone (15 to $18 \%$ ), the Eau Claire Formation (17 and $19 \%$ ), and the Mt. Simon Sandstone (10 and 15\%). The $n$ values from all of the sandstone units in the storage area are higher than the previously reported values of Buschbach and Bond [6]. For example, the St. Peter Sandstone within the study area has an $n$ of $25-28 \%$. The consistently higher $n$ values imply more secondary porosity associated with greater amounts of structural deformation in the study area as opposed to other fields from which the reported porosity values were obtained. Examining the $n$ data and the $\mathrm{V}_{\mathrm{sh}}$ data suggests that $\mathrm{a}$ secondary porosity was created during the formation of the LaSalle Anticlinorium.

Whether the enhanced $n$ values are a result of structural deformation or not, the higher $n$ values within the storage field suggest that the younger sandstones are possible pathways and storage areas for migrating gas. The P-wave data confirm that gas has migrated through and accumulated within the St. Peter Sandstone in the southern portion of the storage field. While no information about the presence of gas in deeper formations is available, the similar $n$ values of the New Richmond Sandstone, Franconia Sandstone, Ironton Sandstone, and Galesville Sandstone to the St. Peter Sandstone suggest that gas could accumulate within those formations as well (Table 2).

The gas bubble pattern closely corresponds to the faults and fractures within the bedrock (see Figure 10 and Figure 12 in [5]), suggesting that gas migration may be possible through the faults and fractures. The Franconia, Ironton, and Galesville Sandstones have high porosity values, which was expected. However, in K1, porosity values were around $43 \%$ for the Franconia Sandstone, $46 \%$ for the Ironton Sandstone, and 56\% for the Galesville, which is inconsistent with the two other wells (Table 2). The higher porosity support the hypothesis of significant secondary porosity, possibly attributed to structural deformation, in the north portion of the field.

As stated before, porosity values are high in many of the formations overlying the gas storage reservoir. There is a great potential for gas to be stored in the Galesville Sandstone, Ironton Formation, Franconia Formation, Trempealeau Formation, New Richmond Sandstone, and St. Peter Sandstone. If gas is being captured within formations above the gas storage field, especially in the Galesville Sandstone, then gas would not be expected to have risen to the surficial bedrock immediately after injection. Gas storage in the deep sandstone units above the Eau Claire could explain why only recently gas has been seen at the surface. Gas storage in the Galesville Sandstone could be feasible if gas migration from the A sand of the Eau Claire Formation to the Galesville is accommodated by the faults in the area.

The higher porosity units may provide a possible storage mechanism deeper in the subsurface in the northern section resulting in the lack of identifiable gas near the surface. An alternative hypothesis explaining the lack of near-surface gas in the northern section is that the gas is present within the Shakopee Dolomite, as in the southern block, but a distinct P-wave "gas" signal could not be differentiated as a result of travel through approximately $70 \mathrm{~m}$ of Platteville Formation and St. Peter Sandstone.

\section{Conclusions}

There is strong evidence of structural deformation, fracturing and faulting, throughout the field. A main fault runs through the center of the field separating the northern portion of the gathering system from the southern portion of the gathering system. Within the study area, $n$ values for the sandstones are higher than reported values from other areas, indicating the role of structural deformation on porosity enhancement and on the fluid dynamics of the system. As a consequence of the structural deformation, potential vertical pathways exist. Although no evidence of surficial gas was observed for the northern portion of the storage field, south of the major fault, gas was documented within the near surface bedrock. Structural discontinuities may be a primary mechanism for the vertical migration of the gas; however, the $V_{\text {sh }}$ data indicate that stratigraphic anomalies may also provide vertical pathways. The $\mathrm{V}_{\mathrm{sh}}$ data show a spatial relationship to identified structural deformation, and the alignment of areas with low $\mathrm{V}_{\text {sh }}$ values cannot be ruled out as a potential conduit for gas migration. Whether along structural deformities or through heterogeneous units, gas is migrating vertically upwards from the reservoir. The high-resolution seismic reflection data revealed a gas bubble of unknown concentration near the surface. Potential migration paths, faults and fractures, have been confirmed underlying a major portion of the gas bubble. While the presence of gas in the upper units, the Shakopee Dolomite and the St Peter Sandstone, has been confirmed, the limitations of the seismic equipment prevented additional investigations of the deeper units. The $n$ values of the deeper sandstones suggest that gas could be easily stored within the New Richmond Sandstone, Franconia Sandstone, Ironton Sandstone, and Galesville Sandstone.

\section{References}

[1] Energy Information Administration (EIA). "The basics of underground natural gas storage." 2004. [Online]. Available: http://www.eia.doe.gov/pub/oil_gas/natural_gas/analysis_publicati ons/storagebasics/storagebasics.html. [Accessed March 14, 2015].

[2] Energy Information Administration (EIA). "U.S. natural gas summary." 2006. [Online]. Available:

http://tonto.eia.doe.gov/dnav/ng/ng_sum_lsum_dcu_nus_m.htm. [Accessed November 30, 2014].

[3] Nissen, S.E., Watney, W.L., and Xia, J., "High-Resolution seismic detection of shallow natural gas beneath Hutchinson, Kansas," Environmental Geosciences, 11(3), 129-142. 2004.

[4] Blondin, E. and Mari, J.L., "Detection of Gas Bubble Boundary Movement," Geophysical Prospecting, 34, 73-93. 1986.

[5] Pugin, A.J.M., Sargent, S.L., and Hunt, L.I. "SH and P-wave seismic reflection using landstreamers to map shallow features and porosity characteristics in Illinois," in SAGEEP 2006 Meeting, Environmental and Engineering Geophysical Society.

[6] Buschbach, T.C. and Bond, D.C., Underground storage of natural gas in Illinois-1973. Illinois State Geological Survey, Champaign, IL, 1974.

[7] Willman, H.B. and Kolata, D.R., The Platteville and Galena groups in northern Illinois. Illinois State Geological Survey, Champaign, IL, 1978. 
[8] Hansel, A.K. and Johnson, W.H., Wedron and Mason groups: lithostratigraphic reclassification of deposits of the Wisconsin Episode, Lake Michigan Lobe area Illinois State Geological Survey, Champaign, IL, 1996.

[9] Nelson, W.J., Structural features in Illinois. Illinois State Geological Survey, 1995.

[10] Nelson, R.S., Kirchner, J.G., and Searight, T.K. "The LaSalle anticline and its influence on Pennsylvanian sedimentation in the LaSalle-Peru area," in 52nd Tri-State Geological Field Conference, 49
[11] Fertl, W.H. and Chilingarian, G.V., "Type and distribution modes of clay minerals from well logging data," Journal of Petroleum Science and Engineering, 3, 321-332. 1990.

[12] Dresser Atlas, Well logging and interpretation techniques: the course for home study. Dresser Atlas, 1982.

[13] Pugin, A.J.M., Larson, T.H., Sargent, S.L., McBride, J.H., and Bexfield, C.E., "Near-surface mapping using SH-wave and Pwave seismic landstreamer data acquisition in Illinois, U.S.," The Leading Edge, 23(7), 677-682. 2004. 